\title{
Применение новых пористых материалов для нужд различных отраслей промышленности
}

\author{
Е. Астахов, к. х. н. ${ }^{1}$, А. Астахова, к. б. н. ${ }^{2}$, П. Царин ${ }^{3}$, \\ И. Колганов, К. т. н. ${ }^{4}$, С. Горобец ${ }^{5}$, А. Дымова ${ }^{6}$
}

\begin{abstract}
Группа компаний "Обнинские фильтры" (далее - ГК "Обнинские фильтры") более 28 лет разрабатывает и производит новые фильтрующие материалы, осваивает современные методы очистки жидкостей и газов, занимается инжинирингом, консалтингом, ведет научные изыскания в области материаловедения и технологий для микрофильтрации. За последние несколько лет ГК "Обнинские фильтры" существенно расширила спектр заказчиков и в настоящее время сотрудничает с предприятиями микроэлектронной, приборостроительной, химической, атомной, машиностроительной, космической, нефтегазовой, металлургической, фармацевтической, пищевой и других отраслей промышленности [1]. Сегодня нашим предприятием на основе собственных НИОКР осуществляется выпуск инновационных пористых материалов - поропластов на основе политетрафторэтилена (ПТФЭ марки Ф-4, ГОСТ 10007-80) и сверхвысокомолекулярного полиэтилена (СВМПЭ) [2]. Об их свойствах, преимуществах и областях применения рассказывается в статье.
\end{abstract}

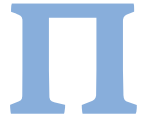
оропласты могут производиться в виде пористых цилиндров различной геометрии, пленок и пластин толщиной от 0,3 до 5 мм и более. Возможно изготовление поропластов в виде композитов с различными наполнителями, например, активированным углем, цеолитами искусственного и природного происхождения и др

Использование поропластов, выпускаемых нашей Группой компаний, для фильтрации жидких и газообразных сред в микроэлектронике описано в предыдущей статье [3]

Выпускаемые поропласты, имеющие открытую пористость, могут быть использованы в процессах массопереноса жидкихи газообразных сред под действием перепада давления, температуры, концентрации, изменения потенциала электромагнитного поля и др. Наиболеераспространенным

ООО "Обнинские фильтры», генеральный директор.

ООО «Экспресс-Эко-Фильтр», генеральный директор.

ООО «нПП Эко-Фильтр», генеральный директор.

ООО "Обнинские фильтры», заведующий лабораторией.

ООО "Обнинские фильтры», заместитель генерального директора

по науке и технологиям

ФГУП ГНЦ РФ Институт медико-биологических проблем РАН,

старший научный сотрудник процессом является фильтрация, однако существует еще целый ряд применений: вентилирование, абсорбция, капиллярный перенос, диффузия и т. п. Кроме того, поропласты могут выполнять конструктивную функцию, в частности для нанесения полимерных мембран.

ПТФЭ - наиболее термохимически стойкий полимер. Он выдерживает воздействие любых растворителей даже при повышенных температурах. Диапазон рабочих температур изделий из пористого ПТФЭ находится в пределах от температуры жидкого азота -193 до $160^{\circ} \mathrm{C}$, ограниченно до $250^{\circ} \mathrm{C}$. Данный материал обладает уникальной для известных полимеров химической инертностью, не разрушается и не выделяет никаких примесей при взаимодействии даже с высокоагрессивными веществами, что делает его незаменимым в микроэлектронной промышленности при работе с особо чистыми жидкостями и газами [4]. Политетрафторэтилен характеризуется наиболее высокой степенью гидрофобности (краевой угол смачивания около 110 $[4,5]$ ).

СВМПЭ по химической стойкости приближен к фторопласту-4 (рабочий диапазон рH 1-14), однако рабочая температура материала лежит в диапазоне от -60 до $100{ }^{\circ} \mathrm{C}$ [6]. Полимер лишь немного уступает ПТФЭ по степени гидрофобности (краевой угол смачивания - около 95 $[7,8])$. 
Таблица 1. Свойства поропластов из фторопласта-4 производства ГК «Обнинские фильтры"

\begin{tabular}{|c|c|c|c|c|c|c|c|c|c|}
\hline $\begin{array}{l}\text { Техническая } \\
\text { марка/ } \\
\text { торговая } \\
\text { марка }\end{array}$ & $\begin{array}{c}\text { Вид } \\
\text { мате- } \\
\text { риала }\end{array}$ & $\begin{array}{l}\text { Геометрия } \\
\text { материала }\end{array}$ & $\begin{array}{c}\text { Тол- } \\
\text { щина, } \\
\text { мм }\end{array}$ & $\begin{array}{c}\text { Пори- } \\
\text { стость, } \\
\%\end{array}$ & $\begin{array}{c}\text { Диапазон } \\
\text { средних } \\
\text { размеров } \\
\text { пор, мкм }\end{array}$ & 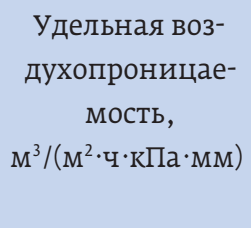 & $\begin{array}{c}\text { Давление } \\
\text { продав- } \\
\text { ливания } \\
\text { воды, } \\
\text { мбар }\end{array}$ & $\begin{array}{l}\text { Проч- } \\
\text { ность } \\
\text { на раз- } \\
\text { рыв, } \\
\text { МПа }\end{array}$ & $\begin{array}{c}\text { Раз- } \\
\text { рывное } \\
\text { удли- } \\
\text { нение, } \\
\text { \% }\end{array}$ \\
\hline $\begin{array}{l}\text { ФМ-100/ } \\
\text { «ЭКОПЛАСТ-Е» }\end{array}$ & $\begin{array}{l}\text { Пори- } \\
\text { стые } \\
\text { цилин- } \\
\text { дры }\end{array}$ & $\begin{array}{c}\text { Наружный } \\
\text { диаметр } \\
\text { цилин- } \\
\text { дров от } 10 \\
\text { до } 150 \text { мм, } \\
\text { высота от } 40 \\
\text { до } 250 \text { мм }\end{array}$ & $2-40$ & $35-55$ & $0,5-50$ & $0,5-100$ & $20-1000$ & $2-4$ & $40-90$ \\
\hline $\begin{array}{l}\text { ФМ-400 / } \\
\text { «ЭКОПЛЕН-F» }\end{array}$ & $\begin{array}{c}\text { Пленки } \\
\text { или } \\
\text { пла- } \\
\text { стины }\end{array}$ & $\begin{array}{c}\text { Пленка } \\
\text { в виде } \\
\text { рулонов } \\
\text { шириной } \\
\text { до } 260 \text { мм }\end{array}$ & $0,25-0,5$ & $40-60$ & $0,5-5$ & $50-300$ & $200-1000$ & $3-6$ & $50-120$ \\
\hline
\end{tabular}

Свойства выпускаемых ГК «Обнинские фильтры» изделий из поропластов представлены в табл. 1 и 2. Структуры материалов показаны в виде фотографий, полученных с использованием электронного микроскопа марки Inspect S производства компании FEI (рис. 1 и 2).

Выпускаемые ГК «Обнинские фильтры» поропласты проявили себя не только в промышленной микрофильтрации, но и в новом, порой уникальном, качестве. Например, в качестве аэраторов, компенсаторов давления в автомобильной и аэрокосмической промышленности, дыхательных перегородок, пористых носителей и для других применений, где востребована проницаемость материалов.
Пористая структура и свойства данных поропластов открывают новые возможности для использования в других технических областях:

1. В микроэлектронике в качестве пористых изделий и фильтров с низкими диэлектрическими проницаемостями и малыми диэлектрическими потерями. Удельная электропроводность может регулироваться благодаря варьированию пористости, размеров пор и толщины (геометрических размеров).

2. В высокочастотной технике из-за низкого уровня поглощения энергии пористые материалы на основе фторопласта-4 могут быть использованы, например, при изготовлении антенных

Таблица 2. Свойства поропластов из СВМПЭ производства ГК "Обнинские фильтры»

\begin{tabular}{|c|c|c|c|c|c|c|c|}
\hline $\begin{array}{l}\text { Техническая } \\
\text { марка/ } \\
\text { торговая марка }\end{array}$ & $\begin{array}{c}\text { Вид } \\
\text { материала }\end{array}$ & $\begin{array}{l}\text { Геометрия } \\
\text { материала }\end{array}$ & $\begin{array}{c}\text { Пори- } \\
\text { стость, \% }\end{array}$ & $\begin{array}{c}\text { Диапазон } \\
\text { средних } \\
\text { размеров } \\
\text { пор, } \\
\text { мкм }\end{array}$ & $\begin{array}{c}\text { Удельная } \\
\text { воздухопрони- } \\
\text { цаемость, } \\
\mathrm{M}^{3} /\left(\mathrm{M}^{2} \cdot \mathrm{q} \cdot \mathrm{k} а \cdot \mathrm{MM}\right)\end{array}$ & $\begin{array}{c}\text { Прочность } \\
\text { на разрыв, } \\
\text { мПа }\end{array}$ & $\begin{array}{c}\text { Раз- } \\
\text { рывное } \\
\text { удлине- } \\
\text { ние, } \\
\text { \% }\end{array}$ \\
\hline $\begin{array}{l}\text { ФМ-101/ } \\
\text { «ЭКОПЛАСТ-РЕ» }\end{array}$ & $\begin{array}{l}\text { Пористые } \\
\text { цилиндры }\end{array}$ & $\begin{array}{c}\text { Наружный диа- } \\
\text { метр цилиндров } \\
\text { от } 10 \text { до } 150 \text { мм, } \\
\text { высота } \\
\text { от } 40 \text { до } 250 \text { мм }\end{array}$ & $35-50$ & $1-100$ & $2-50$ & $3-7$ & $20-50$ \\
\hline $\begin{array}{l}\text { ФМ-401/ } \\
\text { «ЭКОПЛЕН-РЕ» }\end{array}$ & $\begin{array}{l}\text { Пленки } \\
\text { или пла- } \\
\text { стины }\end{array}$ & $\begin{array}{l}\text { Пленки или пла- } \\
\text { стины шириной } \\
\text { до } 280 \text { мм }\end{array}$ & $35-50$ & $2-50$ & $100-1500$ & $2-8$ & $20-60$ \\
\hline
\end{tabular}




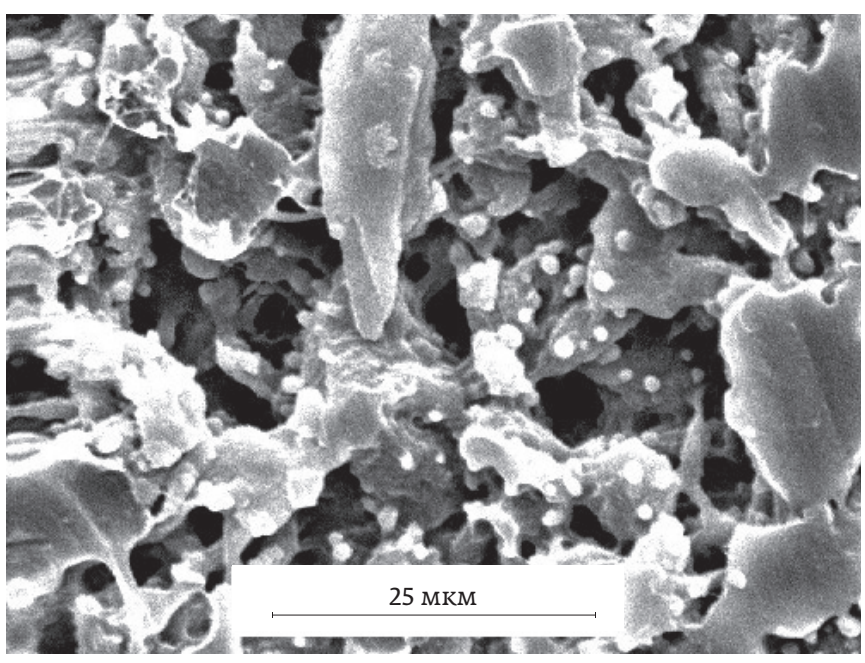

Рис. 1. Электронно-микроскопическая фотография пористой пленки на основе фторопласта-4

и телекоммуникационных устройств. Благодаря особым свойствам поверхности на нее можно наносить металлы или печатать изображения. Данные термостойкие поропласты могут быть изготовлены с жесткой или гибкой структурой.

3. В качестве сепараторов для разделения различных жидких и газообразных сред, в том числе высокоагрессивных.

4. Для защиты датчиков от пыли и аэрозолей; при этом обеспечивается быстрая диффузия газов.

5. В качестве вентиляционных пористых перегородокдля выравнивания давления и обеспечения быстрой диффузии газа при одновременном отталкивании пыли, масла или водного аэрозоля.

6. Для фильтрации сжатого воздуха до степени очистки 0,2 мкм во всех отраслях промышленности.

7. В пневматических системах - для повышения надежности, эффективности и долговечности. Поропласты на основе СВМПЭ могут применяться в качестве пневматических глушителей для эффективного уменьшения шума оборудования

8. При электрохимических измерениях, в электрохимических ячейках и т. п. устройствах в качестве гермовыводов, для изготовления полупроницаемых электродов, в качестве носителей катализаторов, а также возможно использование поропластов с различным рейтингом фильтрации в качестве компенсаторов давления.

9. В химических источниках тока, в том числе в аккумуляторах, для создания полупроницаемой перегородки и защиты электродов от разрушения.

10. В фольгированных диэлектриках в качестве диэлектрической подложки вместо монолитной пленки из пТФЭ. Новые свойства пористыхпленок, такие как

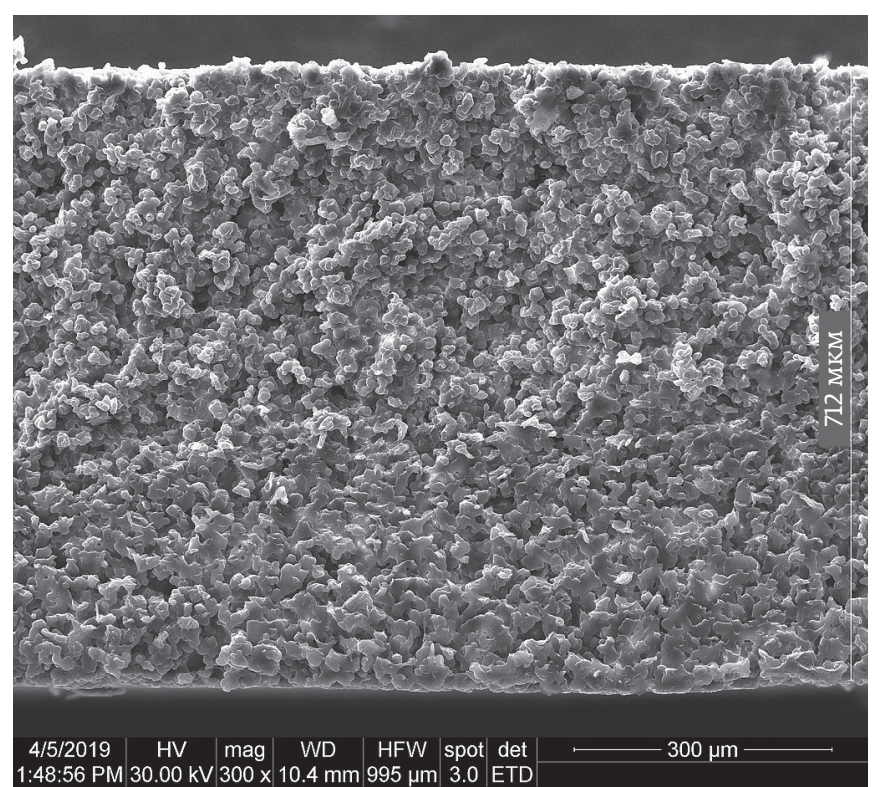

Рис. 2. Электронно-микроскопическая фотография пористой пленки из СВМПэ

гибкость, пористость, а также улучшенные по сравнению с монолитным ПТФЭ диэлектрические свойства, дают основание полагать, что можно получить более качественный продукт.

11. В ламинированных листовых материалах для уплотнений. Пористые пленки могут быть использованы как индивидуально, так и в виде прочного слоистого материала.

Существует мировой опыт применения поропластов в различных технических областях. К сожалению, этот опыт недостаточно используется отечественными производителями.

Новые уникальные свойства получаемых материалов позволят существенно расширить сферы применения данных поропластов. Ниже представлен перечень направлений, в которых поропласты наиболее востребованы в мировой практике.

Пористые пленки из чистого ПТФЭ используются в качестве:

- носителей твердой фазы в хроматографических колонках в жидкостной и гель-хроматографии;

- акустических вентиляционных диафрагм для мобильных электронных устройств;

- вентиляционных пористых перегородок в резервуарах для чернил, которые позволяют вентилировать системы подачи в принтерах, в то же время препятствуя проливанию чернил из емкости.

Поропласты из СВМПЭ могут применяться:

- в качестве подложек для хрупких мембран;

- в системах порошкового покрытия в качестве подложек для псевдоожиженного слоя. Благодаря 
постоянному размеру пор и контролируемому режиму изготовления обеспечивается равномерное распределение порошка вследствие равномерного распределения потока воздуха.

В медицине расширяются сферы применения поропластов из биологически инертных полимеров ПТФЭ и СВМПЭ в виде имплантатов, биопротезов, мембран для оксигенаторов, материалов и фильтров для биотехнологий, воздушных фильтров для капельниц и т. п. Поропласты используются в аналитических целях, при диагностике in vitro, при молекулярных диагностических процедурах. Они находят применение в качестве наконечников для пипеток и деталей пробоотборников с целью защиты от пыли и аэрозолей, носителей при экстракции и концентрировании.

В текстильной, автомобильной и мебельной промышленности поропласты из СВМПЭ могут применяться в качестве вакуумных прижимных листов для разделочных столов.

В настоящий момент нашим предприятием проводится комплекс научно-технологических и опытноконструкторских работ по выпуску пористых материалов из композитных материалов на основе СВМПЭ.

В табл. 3 показаны свойства поропластов из композитных материалов на основе СВМПЭ с различными наполнителями.

Поропласты из композитных материалов имеют двойной механизм очистки жидких и газообразных сред: они очищают фильтруемые среды от твердых и коллоидных частиц (глубинный механизм удержания частиц) и от растворенных веществ (сорбционный механизм удержания). Данные свойства материалов могут быть использованы в различных отраслях промышленности.

Возможно изготовление композиционных поропластов с порошковыми или волокнистыми наполнителями, придающими новые товарные свойства, например электропроводность.

На рис. 3 показана фотография структуры пористой пленки из композита СВМПЭ с активированным углем.

Уникальность материалов на основе смеси полимеров (СВМПЭ) и цеолитов связана с твердой пористой структурой полученных пленок, с различной степенью смачивания водой: у СВМПЭ поверхность гидрофобная, а у цеолитов - гидрофильная. Соответственно в зависимости от степени сродства к различным жидкостям данные материалы будут проявлять либо олеофильные, либо олеофобные свойства, либо оба свойства одновременно. Химическая стойкость данных материалов к кислотам и щелочам определяется стойкостью цеолитов, а по отношению к маслам и углеводородам - стойкостью СВМПЭ.

Пористые материалы на основе фторопласта-4 и сверхвысокомолекулярного полиэтилена, изготавливаемые в виде блоков и пленок, в силу своих особых свойств (высокая химическая и термическая стойкость,

Таблица 3.Свойства поропластов из композитных материалов на основе Свмпэ производства ГК "Обнинские фильтры"

\begin{tabular}{|c|c|c|c|c|c|c|c|}
\hline Наполнитель & $\begin{array}{l}\text { Геометрия } \\
\text { материала }\end{array}$ & $\begin{array}{c}\text { Общая } \\
\text { пори- } \\
\text { стость, \% }\end{array}$ & $\begin{array}{c}\text { Размер пор: } \\
\text { максимальный / } \\
\text { средний, мкм }\end{array}$ & $\begin{array}{l}\text { Удельная } \\
\text { производи- } \\
\text { тельность } \\
\text { по воздуху }\end{array}$ & $\begin{array}{c}\text { Прочность } \\
\text { на разрыв, } \\
\text { мПа }\end{array}$ & $\begin{array}{c}\text { Разрывное } \\
\text { удлине- } \\
\text { ние, } \\
\text { \% }\end{array}$ & $\begin{array}{c}\text { Рабочий } \\
\text { диапазон } \\
\text { рН }\end{array}$ \\
\hline $\begin{array}{l}\text { Активирован- } \\
\text { ный уголь (50\%) }\end{array}$ & $\begin{array}{c}\text { Полый } \\
\text { цилиндр диа- } \\
\text { метром } 65 \text { мм } \\
\text { и высотой } 250 \text { мм }\end{array}$ & $60 \pm 5$ & $10 / 3$ & $\begin{array}{c}250 \pm 20 \\
\text { л / (ч·火Па) }\end{array}$ & - & - & $1-14$ \\
\hline $\begin{array}{l}\text { Активирован- } \\
\text { ный уголь (30\%) }\end{array}$ & $\begin{array}{c}\text { Пленка толщи- } \\
\text { ной 1-1,5 мм }\end{array}$ & $50 \pm 4$ & $8 / 2$ & $\begin{array}{c}45 \pm 15 \\
\mathrm{M}^{3} /\left(\mathrm{M}^{2} \cdot \mathrm{q} \cdot \mathrm{k} \Pi \mathrm{a}\right)\end{array}$ & 5,4 & 28 & $1-14$ \\
\hline $\begin{array}{l}\text { Природный } \\
\text { цеолит (30\%) }\end{array}$ & $\begin{array}{c}\text { Пленка толщи- } \\
\text { ной 1-1,5 мм }\end{array}$ & $42 \pm 3$ & $7 / 1$ & $\begin{array}{c}10 \pm 3 \\
\mathrm{M}^{3} /\left(\mathrm{M}^{2} \cdot \mathrm{q} \cdot \mathrm{k} \Pi \mathrm{a}\right)\end{array}$ & 5,6 & 63 & $2-11$ \\
\hline $\begin{array}{l}\text { Искусственный } \\
\text { цеолит марки } \\
\operatorname{NaA}(30 \%)\end{array}$ & $\begin{array}{c}\text { Пленка толщи- } \\
\text { ной 1-1,5 мм }\end{array}$ & $38 \pm 2$ & $4 / 1$ & $\begin{array}{c}17 \pm 1 \\
\mathrm{M}^{3} /\left(\mathrm{M}^{2} \cdot \mathrm{q} \cdot \mathrm{k} \Pi \mathrm{a}\right)\end{array}$ & 5,3 & 106 & $3-11$ \\
\hline $\begin{array}{l}\text { Искусственный } \\
\text { цеолит марки } \\
\operatorname{NaX}(30 \%)\end{array}$ & $\begin{array}{c}\text { Пленка толщи- } \\
\text { ной 1-1,5 мм }\end{array}$ & $47 \pm 2$ & $5 / 1$ & $\begin{array}{c}10 \pm 1 \\
\mathrm{M}^{3} /\left(\mathrm{M}^{2} \cdot \mathrm{q} \cdot \mathrm{k} \Pi \mathrm{a}\right)\end{array}$ & 2,2 & 12 & $2-11$ \\
\hline
\end{tabular}




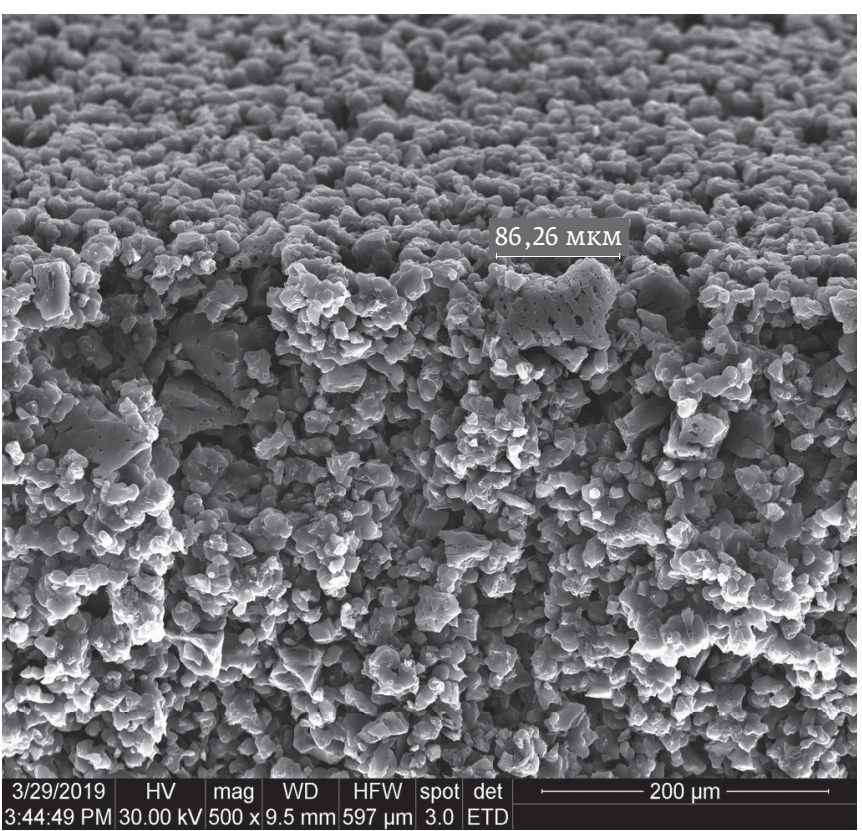

Рис. 3. Электронно-микроскопическая фотография пористой пленки на основе композита из 70\% СВМПЭ и $30 \%$ активированного угля

низкая диэлектрическая проницаемость, гидрофобность) могут применяться в микро-и радиоэлектронной промышленности в качестве сепараторов и фильтров для очистки и разделения любых жидких и газообразных сред с температурами от -60 до $160^{\circ} \mathrm{C}$, вентиляционных пористых перегородок и диафрагм, для защиты датчиков, в качестве носителей и подложек для различных материалов, в электрохимических источниках тока.

\section{ЛИТЕРАТУРА}

1. Котова А. Ю. Четверть века фильтрам «Экспресс-Эко»! // Фармацевтические технологии и упаковка. 2016. Т. 272 № 6. C. 42-43.

2. Астахов Е. Ю., Больбит Н. М., Клиншпонт Э.Р. Характеристики пористых пленок политетрафторэтилена, полученных из суспензий порошков в спирте // Высокомолекулярные соединения. Серия А. 2007. Т. 49. № 2. C. 296-302.

3. Астахов Е., Астахова А., Царин П., Колганов И., Горобец С. Применение термохимически стойких фильтрующих материалов в микроэлектронной промышленности // ЭЛЕКТРОНИКА: Наука, Технология, Бизнес. 2019 № 7. С. 128-132.

4. Пашнин Ю.А., Малкевич С. Г., Дунаевская Ц. С. ФТоропласты. - Л.: Химия, 1978. 232 с.

5. Chaudhuri R. G., Paria S. Dynamic contact angles on PTFE surface by aqueous surfactant solution in the absence and presence of electrolytes // Journal of Colloid and Interface Science. 2009. V. 337. Is. 2. P. 555-562.

6. Андреева И. Н., Веселовская Е. В., Наливайко Е.И. и др. Сверхвысокомолекулярный полиэтилен высокой плотности. - Л.: Химия, 1982.80 С.

7. Du Z., Wang J., Wen S., Wang P., Zhang D., Yin C. Study on the Properties of UHMW-PE Film // Advances in Materials Physics and Chemistry. 2015. V. 5. No. 8. P. 337-343.

8. Kinnari T. J., Esteban J., Zamora N., Fernandez R., LópezSantos C., Yubero F., Mariscal D., Puertolas J. A., GomezBarrena E. Effect of surface roughness and sterilization on bacterial adherence to ultra-high molecular weight polyethylene // Clinical Microbiology and Infection. 2010. V. 16. Is. 7. P. 1036-1041.

\section{КНИГИ ИЗДАТЕЛЬСТВА «ТЕХНОСФЕРА»}

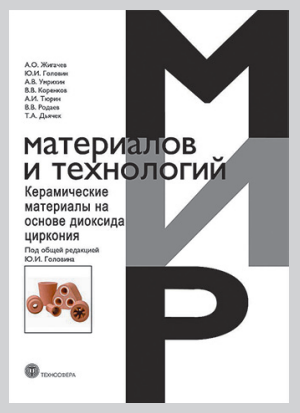

Цена 760 руб.

\section{КЕРАМИЧЕСКИЕ МАТЕРИАЛЫ НА ОСНОВЕ ДИОКСИДА ЦИРКОНИЯ}

Жигачев А. О., Головин Ю. И., Умрихин А. В., Коренков В. В., Тюрин А. И., Родаев В. В., Дьячек Т. А.

Под общей редакцией Ю. И. Головина

В книге обобщены данные по возможному химическому составу, кристаллической и микроструктуре, а также свойствам керамических материалов на основе диоксида циркония. Рассмотрены наиболее развитые технологии получения этих керамик и композитов на их основе. Монография состоит из четырех частей, каждая из которых освещает определенную область вопроСов, связанных с керамическими материалами.

Книга будет интересна широкому кругу читателей: от студентов естественно-научных специальностей до инженеров, технологов и медицинских работников, связанных с практическим применением циркониевой керамики.

Разработка методов синтеза, получение и подготовка оригинальных керамических образцов на основе бадделеита выполнены при поддержке гранта Российского научного фонда (проект № 16-19-10405). Отработка методик исследования и определение физико-механических характеристик осуществлены при поддержке гранта Министерства образования и науки Российской Федерации (проект № 16.2100.2017/П4).

КАК ЗАКАЗАТЬ НАШИ КНИГИ?

$凶$ 125319, Москва, а/я 91; + +7 495 234-0110; 圆 +7 495 956-3346; knigi@technosphera.ru, sales@technosphera.ru 


\section{PBWER M ElFETRONICS}

16-я Международная выставка компонентов и модулей силовой электроники

\section{2-24 октября 2019}

Москва, Крокус Экспо

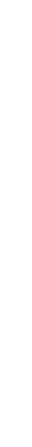

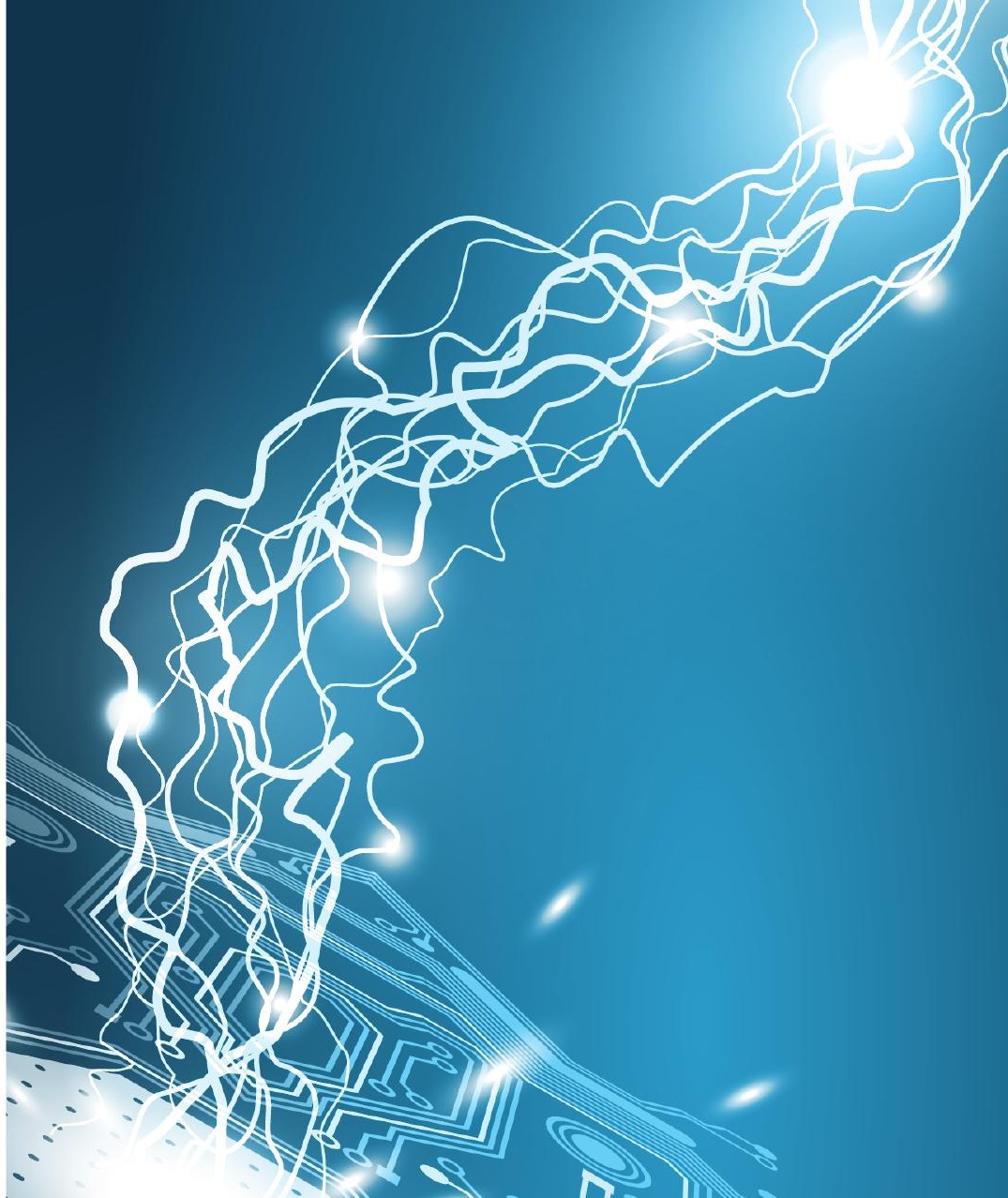

Силовая sufi
כлектроника

Единственная в России специализированная

выставка компонентов

и модулей силовой электроники для различных отраслей

промышленности

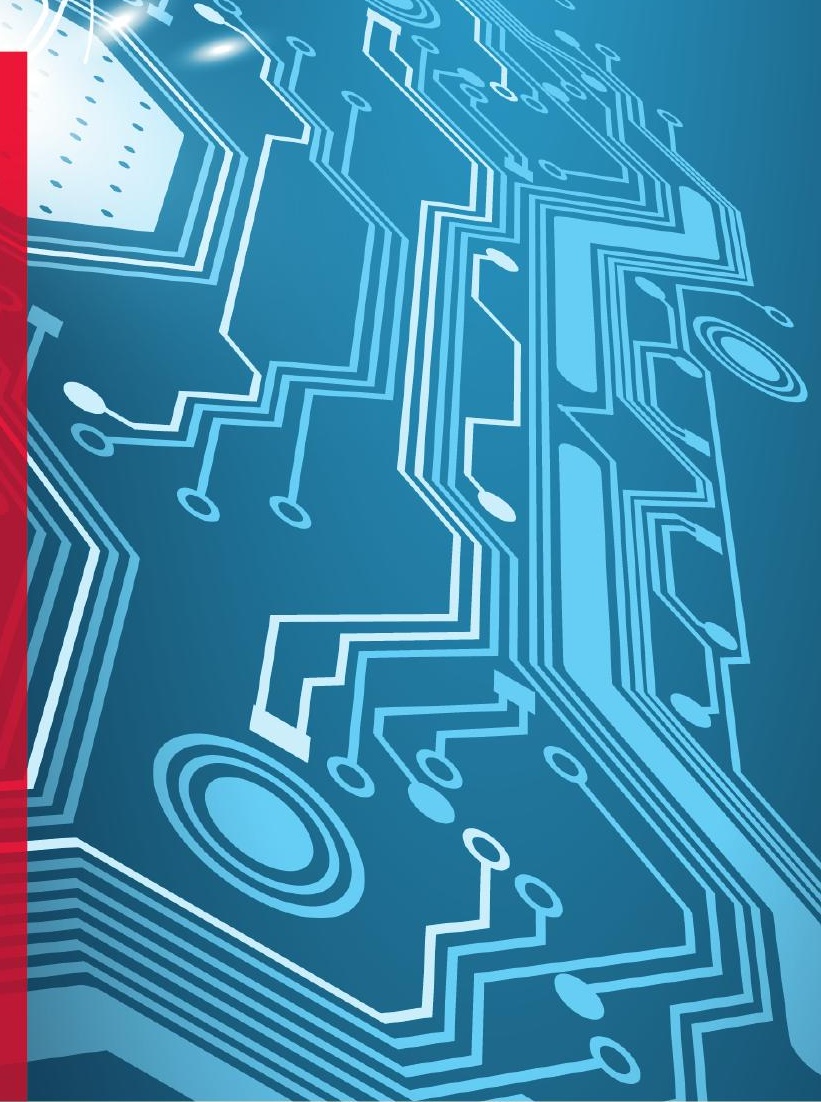

Организатор - компания MVK

Офис в Санкт-Петербурге

\section{$\mathrm{N} \mathbf{V}=$}

+7 (812) 380 6009/00 power@mvk.ru
Подробнее о выставке: powerelectronics.ru
12+ 